DOI https://doi.org/10.36059/978-966-397-141-4/123-141

\title{
FEATURES OF ADMINISTRATIVE AND LEGAL STATUS OF CERTAIN CATEGORIES OF PUBLIC OFFICIALS
}

\section{Lehka O. V.}

\section{INTRODUCTION}

Today, economic and social reforms, informatization, processes of globalization, Ukraine's intentions to join the European community, and new requirements for the formation of the apparatus of civil servants, as it is the state service plays an important role in the system of power relations, acting as one of the leading factors of the unity of the state, about The unification of the efforts of the branches of power, ensuring the arrival of the most experienced civil servants to the state administration bodies.

The need for reform of the civil service in Ukraine has been recognized as one of the priority reforms of our state as a national one (Ukraine-2020 Sustainable Development Strategy and National Security Strategy of Ukraine) and internationally (Resolution of the Parliamentary Assembly of the Council of Europe "The Functioning of Democratic Institutions in Ukraine” from January 25, 2017 (paragraph 10.4.) and the updated Memorandum on Economic and Financial Policies between Ukraine and the International Monetary Fund of March 2, 2017 (paragraphs 17 and $21 \mathrm{~b}$ ). As we see, the process of civil service reform Ukraine has been given a powerful impetus by adopting a new version of the Law of Ukraine "On Civil Service".

The main stories of the Law of Ukraine of 2015 are the with drawal of political positions and positions of patronage service beyond the limits of its limits, positions of employees who perform maintenance functions and auxiliary functions; the establishment of an institution of state secretaries, open competitive selection and political impartiality of civil servants; the establishment of requirements for candidates for the post of senior civil service requirements to know not only the state language, but also one of the official languages of the Council of Europe.

"The study of the civil service system and the construction of its general theory is a complex, multidimensional problem that has not yet 
received a holistic scientific interpretation”, noted V.B. Averyanov ${ }^{1}$. The modern legal institute of civil service is, first of all, a system of legal norms regulating the relations that are formed in the process of organization of the civil service itself, the status of civil servants, guarantees and procedures for its implementation, as well as the mechanism for passing civil service. According to V.B. Averyanov, the civil service is a comprehensive legal institution that regulates the organization and activities of all civil servants and consists of legal norms of various branches of law. The complexity of the civil service institute is that, firstly, it combines the legal norms of other branches of law, and secondly, consists of separate subinstitutions (service of service, principles of civil service, etc.) ${ }^{2}$.

Y.P. Betyak claims that traditionally the civil service is considered in three aspects: social, political and legal. However, the lawyer emphasizes that the notion of civil service should be comprehensive, take into account all aspects, but when it is developed, it is necessary to abandon a number of elements that can be considered as independent phenomena or those that have little effect on the notion of civil service. In his opinion, the civil service is carried out on the basis of the Constitution, the laws of Ukraine on the formation of the apparatus of state bodies and other state organizations, the professional activities of persons holding positions in state bodies and state organizations, on the practical implementation of functions and socially important tasks of the state, provision of the rights and freedoms of citizens, which is paid at the expense of state funds" ${ }^{3}$.

G.I. Lelikov believes that the civil service is a complex, integral system, which has the following aspects: political - a link that connects citizens with the state; legal - practical fulfillment of official duties and powers in the state apparatus; social - the fulfillment of the goals and functions of the state in society. Its state-legal form, administrative-legal and procedural mechanisms of realization are based on the actions of social functions and social nature and are determined by them ${ }^{4}$. S.D. Dubenko,

\footnotetext{
${ }^{1}$ Державне управління: проблеми адміністративно-правової теорії та практики / за заг. ред. В. Б. Авер'янова. К.: Факт, 2003. 384 с.

2 Державне управління: теорія і практика /за заг. ред. В. Б. Авер'янова. К.: Юрінком Інтер, 1998. 432 с.

${ }^{3}$ Битяк Ю. П. Державна служба в Україні: організаційно-правові засади: монографія. Х.: Право, 2005. 304 с.

${ }^{4}$ Леліков Г. І. Організаційно-правові засади формування і функціонування державної служби в Україні: дис. ... канд. юрид. наук: 12.00.07. К., 1999. 173 с.
} 
investigating the legal aspect of the civil service, argues that this is a system of legal norms regulating state service relations, that is, rights, duties, restrictions, prohibitions, incentives, employees' liability, civil service, the order of occurrence and termination of official relations ${ }^{5}$.

Thus, acting as an element of a state-organized society, the civil service has a number of peculiarities, in particular: it represents the sphere of professional activity (the content, forms and methods of the activity of civil servants are aimed at ensuring the powers of state bodies); is intended to protect the rights, freedoms and legitimate interests of participants in public relations (the constitutional provision that a person, his rights and freedoms is the most important value ${ }^{6}$, acts as the main pillar in the activities of civil servants, regardless of official status); a peculiar form of reflection of public relations and relations, an indicator of the degree of humanity and existing in the society of the order; public service not only reflects social relations and relations, it has a social orientation aimed at bringing the constitutional ideal of a legal democratic state closer to objective reality ${ }^{7}$.

Consequently, the civil service represents an integral part of public administration, is its leader, embodies all tasks set before the state and is the object of administrative influence.In the context of reforming the system of public administration, improving the current legislation on public service and adapting the civil service institution to the standards of the European Union, the issue of the legal status of a civil servant and the peculiarities of its legal regulation becomes especially relevant, as the construction of a professional and efficient civil service is impossible without highly qualified civil servants with the corresponding level of professional competence.The study of the legal status of a civil servant was given attention by V.B. Averyanov, D.V. Baluch, L.R. Bila-Tyunova, Y.P. Bytiak, V.V. Vasylkivska, I.P. Golosnichenko, S.D. Dubenko, M.I. Inshin, S.V. Kivalov, T.O. Kolomoets, L.M. Kornuta, I.V. Megadin, N.R. Nizhnik, G.V. Padalko, O.M. Stets and others.

However, the development of the public service, the adaptation of the civil service institute to the standards of the European Union, and the improvement of the current legislation on civil service (the adoption of the Laws

${ }^{5}$ Дубенко С. Д. Державна служба і державні службовці в Україні. К.: Видавничий Дім «Ін-Юре», 1999. 242 с.

${ }_{6}^{6}$ Конституція України. Відомості Верховної Ради України. 1996. № 30. Ст. 141 (із змінами).

${ }^{7}$ Іншин М. І. Особливості правового регулювання державної служби в Україні: сучасний стан, проблеми, перспективи розвитку. Форум права. 2013. № 2. С. 165-179. 
of Ukraine “On Civil Service”, “On Prevention of Corruption”) necessitate a rethinking of a whole range of scientific and theoretical provisions, the part concerning the legal regulation of the status of a civil servant.

\section{Legal regulation of the status of civil servant}

According to Part 2 of Art. 1 of the Law of Ukraine "On Civil Service", a civil servant is a citizen of Ukraine who holds a civil service in a government body, another state body, his staff (secretariat), receives wages at the expense of the state budget and implements the established for this office powers directly related to the execution of the tasks and functions of such a public authority, and also adheres to the principles of civil service ${ }^{8}$.

The tasks and functions of the civil service by their nature predetermine the need to consolidate the duties first and then - service rights. Duties of the civil servant determine the essence of his official activities, outline the tasks set, determine the boundaries of the required occupational behavior. The rights are also aimed at ensuring the proper conditions for the performance of official activities, the creation of real opportunities for the performance of official tasks.

Legal regulation of civil service, in accordance with Art. 5 of the Law of Ukraine "On Civil Service" is implemented by the Constitution of Ukraine, other laws of Ukraine, international treaties, the consent of which is binding on the Verkhovna Rada of Ukraine, resolutions of the Verkhovna Rada of Ukraine, decrees of the President of Ukraine, acts of the Cabinet of Ministers of Ukraine and central executive authorities, which ensures the formation and implementation of public policy in the field of civil service. The features of the legal regulation of the civil service in the justice system are determined by the legislation on the judicial system and the status of judges ${ }^{9}$.

Legislative regulation of the status of a civil servant, depending on the type of civil service, has certain features:

- administrative service: a) general legislative acts (laws of Ukraine “On Civil Service”, “On Prevention of Corruption”, "On Purge of Power”, Code of Administrative Justice of Ukraine); b) special (Law of Ukraine “On Diplomatic Service”, etc.);

${ }^{8}$ Про державну службу: Закон України від 10 грудня 2015 р. № 899-VIII. Oфіичійний вісник України. 2016. № 3. Ст. 149. [Електронний ресурс]. URL: http://zakon. rada.gov.ua.

${ }^{9}$ Там само. 
- specialized service (there is no general legislative act, the action of which would extend to this type of service, each subspecies of this type of service has its own special law);

- militarized service (integral substantially defined subordinate legal structure, which is made up of relatively independent subspecies of this kind of service (military service, border guard service, SBU, law enforcement service, state security service, civil protection, special communication service, etc.), which are characterized by general legislative acts (statutes), and special legislative acts.

The division of civil servants is carried out according to different criteria depending on which the following types of civil servants are distinguished: a) by the nature of labor and the volume and nature of their official powers: managers, specialists, technical executors; b) by the nature and volume of authority: officials (representatives of the authorities, administrative and auxiliary staff, functional (operational, main) personnel); c) by type of service in which persons are: employees of ordinary (civil) service; employees of the special (militarized) service; d) according to the distribution of state power: civil servants of the legislative branch; civil servants of executive power; civil servants of the judiciary.

Public service positions in state bodies are divided into categories, depending on the order of appointment, the nature and extent of powers and the necessary qualifications and professional competence of civil servants for their fulfillment. Three categories of civil service positions are established:

- category "A" (senior civil service) - positions: State Secretary of the Cabinet of Ministers of Ukraine and his deputies, state secretaries of ministries; heads of central executive bodies, who are not members of the Cabinet of Ministers of Ukraine, and their deputies; the heads of the apparatus of the Constitutional Court of Ukraine, the Supreme Court, the high specialized courts and their deputies, the heads of the secretariats of the High Council of Justice, the High Qualifications Commission of Judges of Ukraine and their deputies, the Chairman of the State Judicial Administration of Ukraine and his deputies; heads of civil service in other state bodies whose jurisdiction extends over the entire territory of Ukraine;

- category "B" - positions: heads of structural subdivisions of the Secretariat of the Cabinet of Ministers of Ukraine and their deputies; heads of structural subdivisions of ministries, other central bodies of executive power and other state bodies, their deputies, heads of territorial bodies of these state bodies and their structural subdivisions, their 
deputies; heads and deputy heads of structural subdivisions of local state administrations, the apparatus of local state administrations, their structural divisions; heads of the courts of appellate and local courts, heads of structural divisions of court apparatus, their deputies; deputy heads of civil service in other state bodies, whose jurisdiction extends over the entire territory of Ukraine; category " $B$ " - other positions of the civil service not classified in categories "A" and " $B$ ".

The positions of civil servants are classified according to the organizational and legal level of the body, the scope and nature of the authority of a person in a particular position, the role and place of position in the structure of a public authority. The following 3 types of positions are distinguished in state authorities: political, administrative and patronage.

The status of civil servant includes the following elements: rights, responsibilities, restrictions, incentives and guarantees, responsibilities that are organically interlinked. Specific duties and rights of civil servants are determined on the basis of typical qualification characteristics and are reflected in the positions and instructions approved by the heads of relevant state bodies within the limits of the law and their competence.

The subjects of legal regulation of the status of a civil servant are state bodies that, in their competence, exercise their powers in matters of civil service and, in particular, on the right to civil service. For example, the establishment of this right is regulated by the Verkhovna Rada of Ukraine by adopting relevant laws; definition and provision of this right the Cabinet of Ministers of Ukraine, the National Security Service through the issuance of relevant legal acts and the implementation of, respectively, state and functional management in the field of civil service; Protection of this right - administrative courts (judicial protection) and the National Security Service (administrative protection).

\section{General principles of activities and status of civil servants}

The general principles of activity, as well as the status of civil servants working in state bodies and their apparatus, are defined in the Law of Ukraine "On Civil Service". In general, with the adoption of the Law of Ukraine “On Civil Service” in 2015, "reform” took place in the sense of the administrative and legal status of a civil servant. Thus, Section II of this Law defines the legal status of a civil servant, establishes, in addition to basic rights and obligations, and subordination as a consequence of the powers provided for by law. In addition, the principle of political impartiality is an integral element of the legal status 
of a civil servant, that is, "a civil servant must impartially perform statutory orders (orders), orders from directors irrespective of their party affiliation and their political beliefs", he "has no right to demonstrate his political views and other actions or inaction that can in any way testify to his particular attitude towards political parties, to negatively affect the image of the state body and the blasts you trust the government or threaten the constitutional order, territorial integrity and national security, health and the rights and freedoms of others"10.

Also, according to the Law of Ukraine "On Civil Service", the requirements of the educational and qualification level of a civil servant have been reduced. Thus, for example, paragraph 5, part 2, art. 20 stipulates that from persons applying for the post of civil service of category "B", the presence of higher education only the junior bachelor's or bachelor's level and the fluency of the state language is required. However, there are no requirements for the professional level and, accordingly, the length of service. And such civil servants will form the main body of civil service.

The peculiarities of the legal status are also determined by certain general and specific restrictions defined by the civil servants in the Law of Ukraine "On Prevention of Corruption", for example, restrictions on the receipt of gifts (Article 23 of the said Law), restrictions on the combination and combination with other types activities (Article 25), restrictions on the work of close relatives (Article 27). The special legal status of civil servants determines the specifics of their social security, that is, the system of state support and servicing of civil servants.

It is worth paying attention to the fact that today there is no single legal approach from the side of scientists to determine the content of the concepts of "legal status", "legal status of a civil servant”, "administrative and legal status". For example, "legal status" is understood as: a set of rights and obligations of individuals or legal entities ${ }^{11}$; the system of rights, freedoms, responsibilities and responsibilities of the individual enshrined in regulatory legal acts and state guaranteed by the state ${ }^{12}$; a set of all rights, duties and legitimate interests of subjects of law ${ }^{13}$.

${ }^{10}$ Про державну службу: Закон України від 10 грудня 2015 р. № 899-VIII. Oфiu̇iŭний вісник України. 2016. № 3. Ст. 149. [Електронний ресурс]. URL: http://zakon. rada.gov.ua.

${ }^{11}$ Юридична енциклопедія: в 6 т. /за заг. ред. Ю. С. Шемшученка та ін. К.: Українська енциклопедія, 2003. Т. 5: П-С. 736 с.

${ }^{12}$ Про судоустрій та статус суддів: Закон України від 7 липня 2010 р. № 2453-VI. Офіиіийний вісник Украӥни. 2010. № 55/1. Ст. 1900.

13 Загальна теорія держави та права: підручник /М. В. Цвік, О.В.Петров, Л. В. Авраменко та ін.; за ред. М. В. Цвіка, О. В. Петришина. Х.: Право, 2009. 584 с. 
Discussions about the status of a civil servant in Ukraine, indicate a certain instability of its norms, due in part andpolitical nature of the relations in which a civil servant is. At the same time, different approaches to the characterization of the status of a civil servant are noticeable among Ukrainian scholars.

For example, according to IV Meghedin, the main elements of the legal status of a civil servant are: integrity; systematic legal status; the ratio of authority of the position he occupies with the rights and duties arising from the fact of being in the public service; established legal incentives and motivation for the interest of the civil servant in the effective performance of duties; the mechanism of legal liability of civil servants through institutes of administrative, criminal responsibility, norms of labor, financial law, etc.; ensuring the stability of the status of a civil servant with appropriate guarantees, social protection ${ }^{14}$.

Y.P. Bitiyak notes that the legal status of civil servants reflects the essence and content of state-service relations, combines elements of the civil service institute from admission to it until completion. He, in the opinion of the author, is a set of rules of the civil service - rights, duties, restrictions, prohibitions, guarantees, social protection, responsibility ${ }^{15}$.

V.V. Vasilkivska believes that, depending on the type of civil service, the rights of a civil servant are rather diverse, not by subject, but by the way of their normative and legal definition. For servants of the state administrative and state militarized service it is characteristic that their rights are determined by the general (for the administrative service the Law "On Civil Service”) or general (for militarized service - the relevant laws, which applies to all state militarized employees, regardless of the type service) - basic rights, and special laws that regulate in detail the rights of a civil servant depending on the state authority (administrative service) or the type of military service (mileage arisen service) - special rights. In addition, a civil servant has the rights that he has been allocated depending on his position (official rights), which are determined by job descriptions. Instead, for employees of the state specialized service, the rights defined by special laws are characteristic, since they have no general legislative act (special rights) and job descriptions (office rights). V. Vasilkivska's legal status of civil servants

${ }^{14}$ Мегедин I. В. Особливості правового статусу державного службовця. Науковоінформаційний вісник. Серія: «Право». 2013. № 7. С. 157-163.

${ }^{15}$ Битяк Ю. П. Державна служба в Україні: проблеми становлення, розвитку та функціонування: автореф. дис. ... докт. юрид. наук: 12.00.07. Х., 2016. 38 с. 
and the procedure for passing the public service is considered in conjunction with the moral and legal requirements for the behavior of employees, the anti-corruption orientation of the legal principles of the formation and functioning of the civil service, and the problems of training personnel for executive authorities and local self-government ${ }^{16}$.

According to O. Petrishin, the specificity of the activity and legal status of civil servants is “... implementation of internal organization on the basis of direct subordination of management of the relevant team" ${ }^{\prime 17}$. After all, any official, being the holder of authority, performs organizational and administrative functions within the limits of his official duties and has the right to apply coercive measures. In addition to the powers envisaged by the post, this category of employees is also entitled to represent the interests of a particular organizational structure, or organizations in general, in relationships with other actors, in connection with which acts as a special subject of the management process, reflected in his legal status. Therefore, the concept of "legal status" can be formulated as a certain system of capabilities of the person, determining its legal status in the state, distinguishing, in this case, its general and special legal status.

N.R. Nyizhnik formulates the definition of the legal status of a civil servant as established and guaranteed by the state measure of the necessary and possible behavior of a civil servant in the field of state service relations ${ }^{18}$.

There is no consensus among jurists and the definition of the term "administrative and legal status". For example, O. F. Skakun believes that the guarantees of the realization of the rights and obligations of citizens, enshrined in the norms of administrative law, as well as the guarantees of the implementation of these rights and freedoms, are secured by the mechanism of their protection by the authorities for the exercise of rights, freedoms, duties will remain "statements of intentions". However, general social (economic, political, ideological, etc.) and special-social (legal) guarantees are factors for realizing the legal status of a person, and not elements of the structure of his system, since the content of lawful

${ }^{16}$ Васильківська В. В. Правове регулювання статусу державного службовця в Україні: автореф. дис. ... канд.. юрид. наук: 12.00.07. Одеса, 2018. 24 с.

${ }^{17}$ Петришин О. В. Статус службової особи: природа, структура, спеціалізація. К.: НМКВО, 1990.

${ }^{18}$ Нижник Н. Р. Державна виконавча влада в Україні: формування та функціонування. К.: Вид-во УАДУ, 2000. Ч. 1. С. 166-167. 
conduct of a person reveals rights, freedoms and responsibilities, with a specific the type and extent of possible or compulsory behavior. Their external fixation is found in the rules of law. And this means that their realization takes place in certain legal relationships ${ }^{19}$.

A. Vasiliev argues that the content of the administrative and legal status of a citizen is a specific and detailed constitutional rights, freedoms and duties of citizens, enshrined in the norms of administrative law, as well as guarantees of the realization of these rights and freedoms, provided by the mechanism of their protection by the state authorities and local self-governance ${ }^{20}$.

Y.O. Tikhomirov, the administrative and legal status of a citizen defines the rights, duties and responsibilities of a citizen, established by the law and other legal acts, which ensures his participation in the management of the state and the satisfaction of public and personal interests through the activities of state bodies ${ }^{21}$.

In our opinion, the peculiarity of the administrative and legal status of civil servants is that they represent the personnel (or personnel) of executive authorities and local governments. It is through them that the tasks and functions of executive power are implemented at various levels as employees of the relevant state bodies. They are the link of the state management mechanism, through which the state executive authority is implemented, concrete management decisions and the legal acts of management based on them are implemented. Taking into account how properly the civil servants understand the functions, powers and responsibilities assigned to them, the effectiveness of the functioning of practically every state body and the system of public administration depends on the correct way.

It should be noted that a person acquires status only if he is recognized as a legal person.

The legal status of a person determines her place in society, characterized by a certain set of rights, duties, guarantees of their security and liability for non-fulfillment of duties. One of the types of legal status of a certain category of persons is the type of professional activity that is the public service.

${ }^{19}$ Скакун О. Ф. Теория государства и права: учебник. Х.: Консум; Ун-т внутр. дел, 2000. 704 с.

${ }^{20}$ Васильев А. С. Административное право Украины. Х.: Одиссей, 2002. 288 с.

${ }^{21}$ Тихомиров Ю.А. Курс административного права и процесса. М., 1998. 799 с. 


\section{Features of the legal status of certain categories of civil servants}

Let's consider the peculiarities of the legal status of certain categories of civil servants.

For example, the general status of public servants of the prosecutor's office is determined by the Constitution of Ukraine, a special status reflecting the passage of the civil service in the prosecutor's offices, is determined by the tasks and functions of the prosecutor's office, which are envisaged by the Law of Ukraine “On Prosecutor's Office”; the individual administrative and legal status of public servants of the prosecutor's office is determined directly by the relevant official instructions.

Employees of the prosecutor's office are a special kind of civil servants. They perform administrative and law enforcement functions, which are different from other civil servants legal status, since they carry out executive and administrative, control and supervisory, criminalprocedural powers of the law-enforcement order on behalf and on behalf of the state. At the same time, each level of legal status of civil servants of the prosecutor's office is characterized by a certain amount of rights, duties, restrictions, guarantees and responsibilities.

In the opinion of V.I. Babenko, the main characteristics of the administrative and legal status of civil servants of the prosecutor's office include: 1) its settlement with the norms of administrative law; 2) the presence in its composition of certain elements, the main of which are rights and obligations; 3) taking into account the differences between public servants of the prosecutor's office and other civil servants and employees working in the prosecutor's offices; 4) reflection of the essence and content of public-service relations in the prosecutor's offices throughout the term of service - from admission to the civil service until its completion ${ }^{22}$.

In the administrative legal status of civil servants of the public prosecutor's office there are two groups of elements: 1) elements which are enshrined in the status of the corresponding position (official rights and responsibilities, responsibility); 2) elements that are not enshrined in the status of the post (general rights and obligations, restrictions and prohibitions, liability, which apply to civil servants in general and civil servants of the prosecutor's office, in particular).

22 Бабенко В.І. Сутність адміністративно-правового статусу державних службовців органів прокуратури. Наше право. № 4. С. 56-59. 
For the public servant of the prosecutor's office, primary duties are those which determine in general the limits of his legal status. In the process of exercising his rights, the employee operates within the legal limits specified by his duties, including prohibitions. At the same time, taking into account the fact that in the norm of the law there is only a general model of behavior, and specific life situations are much more meaningful, in practical activity of a public servant of the public prosecutor's office there is often a discretion, the scope of which is established by the rules of law that regulate the goals, tasks, institutes of the necessary defense, extreme necessity, and others.

The legal status of civil servants of the internal affairs bodies is regulated by the laws of Ukraine "On Civil Service”, "On the National Police". This is a special category of civil servants who perform administrative and law enforcement functions, have a legal status different from other employees, execute executive and regulatory powers of law enforcement nature on behalf and on behalf of the state. In addition, they enter into legal relations that derive from the content of their official authority not only in the middle of the body or subdivision, but also outside, that is, they enter into relations with citizens, other state and nonstate bodies. Speaking in the said relationship on behalf of the state, they may apply the measures required to comply with lawful requirements, in particular coercive measures. Consequently, employees of the lawenforcement bodies are endowed with powers of state power and are able to enforce the mechanism of state coercion.

In essence, the legal status of a civil servant in the organs of the internal affairs is the measures established and guaranteed by the state and compulsory and possible behavior in the sphere of state service relations. With their change, the legal status of the employee of the internal affairs bodies (for example, increase, decrease, release, retirement, retirement) is transformed.

Thus, the legal status of an officer of the internal affairs bodies is the system of rights, freedoms, duties, restrictions, moral and legal requirements and guarantees of professional activity of a separate category of employees of services and units of the Ministry of Internal Affairs of Ukraine that perform law enforcement tasks in the normative-legal acts. the field of public safety and order, the fight against the offenses, their social and legal protection and the peculiarities of legal liability.

The legal status of civil servants of the judiciary is determined by the laws of Ukraine "On Civil Service”, "On the Judiciary and Status of 
Judges". However, the civil service in the judiciary is not limited to the fulfillment of the tasks and functions provided for by the Law of Ukraine "On the Judiciary and Status of Judges". It is a complex state-legal and social institution that establishes and regulates state relations with court employees; covers the formation of administrative, procedural and sociopsychological foundations of the state apparatus; construction and legal description of the hierarchy of positions; identification, selection, preparation, development, promotion, evaluation, promotion and responsibility of civil servants.

The main features that determine the peculiarities of the administrative and legal status of civil servants of the judiciary include: civil servants of judicial bodies carry out activities in the civil service; carry out practical functions of the state in carrying out judicial oversight of observance of laws in Ukraine; carry out tasks aimed at strengthening the rule of law and protection against unlawful encroachments: the independence of the republic established by the Constitution of Ukraine, the social and state system, political and economic systems, the rights of national groups and territorial entities; guaranteed by the Constitution, other laws of Ukraine and international legal acts of socio-economic, political, personal rights and freedoms of man and citizen; the basis of the democratic system of state power, the legal status of local councils, bodies of self-organization of the population; receive wages at the expense of the state; officials.We are impressed by the position of Y.S. Zolotareva, according to which "the legal status of civil servants of judicial bodies" is a complex of concretely defined subjective rights and obligations that are enshrined in the relevant subject of administrative law. It implies: firstly, the presence of power powers of both internal-organizational and external nature; secondly, the opportunity to speak, within the limits of its competence, on behalf of the state, when exercising supervision over the observance and correct application of laws by public authorities and local self-government bodies, individuals and legal entities, enterprises, institutions and organizations; thirdly, the presence of restrictions imposed both during entry into the civil service and during its passage; Fourthly, the existence of guarantees of social and legal protection; fifth, increased responsibility for both their own actions and for the activity (inactivity) of their subordinate employees ${ }^{23}$,.

23 Золотарьова Я. С. Адміністративні процедури проходження державної служби в судових органах України: автореф. дис. ... канд. юрид. наук: 12.00.07. К., 2016. 24 с. 
The legal status of a civil servant is a generic concept in relation to more specific statuses - a public servant of a public administration body, a judicial administration, etc., which, in turn, perform the same role as more specialized statuses (for example, the status of an employee of the state administration, the status of a civil servant the body of internal affairs). That is, the status of a civil servant of a judicial body is a generic notion of such a category as the legal status of a public servant of a public administration.

It is worth paying attention to the fact that, in accordance with the current Law of Ukraine "On Civil Service", from the list of positions that fall under the civil service, unreasonable withdrawal of aide judges. On this fact the chairman of the Supreme Court of Ukraine A.M. Romanyuk noted: "The volume and nature of the work of the assistant judge can not go beyond the limits of the implementation of a judge of state power through the administration of justice. Moreover, failure to provide the status of civil servants to auxiliary judges will lead to the fact that the Law of Ukraine "On Prevention of Corruption" does not extend to this category of persons, and this can not be considered correct. The absence of a special law that envisages the status of such persons will not only lead to a reduction in the effectiveness of the anti-corruption law, but also to the complete absence of legislative norms, which would determine the legal status of a judge's assistant ${ }^{24,}$.

As to the legal status of civil servants of local self-government, the latter is regulated by the Constitution of Ukraine, the Laws of Ukraine "On Local Self-Government in Ukraine”, "On Local Elections”, “On Elections of Deputies of Local Councils and Village, Settlement, City Mayors”, "On the Service in the bodies of local self-government", "On the status of deputies of local councils" and other legislative acts. An undeniably important aspect of their legal status is the theoretical and practical justification of the current conditions of classification, as well as its role and influence on the formation of the special legal status of civil servants of local self-government. Such a classification, according to G.V. Padalko, makes it possible to establish the real place of civil servants of local selfgovernment in the municipal service hierarchy, to identify their role in local self-government (self-government, municipal administrative) process, to determine the conditions and procedure for service in local self-

${ }^{24}$ Висновок на проект Закону України «Про державну службу» Верховного Суду України. [Електронний ресурc]. URL: http://www.scourt.gov.ua. 
government bodies, to determine the peculiarities of the implementation of organizational and regulatory functions, which, ultimately, will contribute to improving the legal regulation of this type of public service ${ }^{25}$.

In addition, it should be noted that Article 6 of the current Law of Ukraine "On Civil Service" defines a list of civil service positions that fall into the category "A", "B", "B". It should be noted that, unlike the Law of Ukraine "On Civil Service” in 1993 (Part 3, Article 25), which provided for the right of the Cabinet of Ministers of Ukraine to attribute existing and new civil servants to the relevant category not included in the law, the current law does not provide such a right is neither for the Cabinet of Ministers of Ukraine nor for any other state body or its head. That is, the legislator has established an exhaustive list of only positions of categories " $A$ " and "B", which can be changed only by amending this law. According to the explanations of the National Agency of Ukraine on Civil Service dated 10.05.2016 № 6-p/s, "the positions of heads of structural divisions as independent, and in the composition of independent structural subdivisions of the local state administration, their deputies and heads of structural divisions the apparatuses of these administrations belong to the category " $B$ " 26 . However, Art. 6 of the Law to the category " $B$ " refers only to heads of structural subdivisions of "ministries, other central bodies of executive power and other state bodies, their deputies, heads of territorial bodies of these state bodies and their structural subdivisions, their deputies".

In this regard, district state administrations and their departments are ranked within the category " $\mathrm{B}$ ", in others, both in the category and in the category " $\mathrm{B}$ ", the heads of the structural units (in particular, the heads of departments and the heads of the sectors) have been assigned rayon administrations and their vehicles. The analysis of available information from open sources (the sites of the district administrative districts) made it possible to state that the practice of assigning these managers to the category " $\mathrm{B}$ " and assigning them the corresponding $(6,7,8,9)$ rank of civil servant was not sufficient. But with the appointment of the head of the apparatus of local state administrations to the category of civil servants, the situation is the opposite. Despite the position of the National Agency of

${ }^{25}$ Падалко Г. В. Конституційно-правовий статус посадових осіб місцевого самоврядування в Україні. Держава і право. Вип. 55. С. 184-190.

${ }^{26}$ Роз'яснення Національного агентства України з питань державної служби «Щодо віднесення посад керівників структурних підрозділів місцевих державних адміністрацій до відповідних категорій посад державної служби» від 10.05.2016 p. № 6-p/3 [Електронний ресурс]. URL: http://nads.gov.ua/page/shchodo-vidnesennya-posad-kerivnykiv. 
Ukraine on Civil Service, according to which "the position of the head of the apparatus of local state administrations is not currently envisaged in the list of civil service positions of category "B", in a significant number of rayon state administrations the position of the head of the staff is classified as " $B$ ". And only in some cases - to the category " $B$ ".

Another controversial issue is the appointment of heads of local state administrations to the category of civil service positions and the assignment of their respective ranks. From May 1, 2016, the President of Ukraine issued only one Decree "On the Appointment of a Civil Servant", which was awarded to the heads of six oblast state administrations as a civil servant. However, on the website of the Official Online Presidential Office of the President of Ukraine and in the database "Legislation of Ukraine" of the Verkhovna Rada of Ukraine, there are no acts of the Head of State regarding the assignment of the rank of a civil servant to the heads of district state administrations. According to Part 2 of Art. 25 of the Law of Ukraine "On Civil Service" in 1993, the positions of the heads of district state administrations belonged to 3 categories, and they were assigned 7, 6, 5 rank. And according to Art. 6 of the current Law of Ukraine "On Civil Service", positions of heads of local state administrations, incl. heads of district state administrations fall into the category " $A$ " (1, 2, 3 rank). In turn, Part 4, 5 of Art. 39 of the current Law determines that the ranks are assigned to civil servants at the same time as their appointment only by the appointment subject, which is the President of Ukraine in relation to the heads of the MDA (Part 4, Article 118 of the Constitution of Ukraine). That is, the heads of district state administrations appointed to these positions by the President of Ukraine were not assigned to a rank of a civil servant in accordance with the new wording of the Law of Ukraine "On Civil Service".

The specified ambiguity of the application of the Law of Ukraine "On Civil Service” by the subjects of appointment leads to a violation of one of the basic rights of a civil servant - remuneration depending on the position occupied, the results of service activity, seniority of the civil service and rank.

\section{CONCLUSIONS}

Summing up the above, we came to the conclusion.

1. The legal status of a civil servant is derived from the content of the civil service as a legal and organizational institution.

2. The administrative and legal status of a civil servant is a list of subjective rights, legal obligations, guarantees of their implementation, as 
well as restrictions that, in their aggregate, ensure implementation of the authority by the civil servant within the functions and tasks of the civil service, as determined by the current legislation.

3. The status of a post is determined by its establishment and characterizes the position of the civil servant, stipulates the content of the requirements to the applicant for its employment, reflects the essence and content of state-service relations, is a set of rules of the civil service rights, duties, restrictions, prohibitions, guarantees, social security, responsibility. Through these categories, status is developing, and, consequently, the change in public-service relations leads to a change in the legal status of civil servants. The specific rights and obligations of civil servants are determined on the basis of typical qualifications and are reflected in the positions and instructions.

4. The legal status of civil servants and the procedure for passing the public service are considered in combination with the moral and legal requirements for the behavior of employees, the anticorruption orientation of the legal principles of the formation and functioning of the civil service, and the problems of training personnel for executive authorities and local self-government.

5. The subjects of legal regulation of the status of a civil servant are the state bodies which, in their competence, exercise their powers in matters of civil service and, in particular, on the right to a civil service.

6. The question of the administrative and legal status of a civil servant, taking into account the specifics and peculiarities of legal regulation of civil servants, depending on the type of a particular body, not only remain relevant, important and timely, but also become of particular importance in the context of reforming the system of public administration, improving the current the legislation on civil service and the adaptation of the civil service institute to the standards of the European Union.

\section{SUMMARY}

The essence and peculiarities of the concepts of "state service", "civil servant”, "legal status", "administrative-legal status", "legal status of a civil servant" are determined on the basis of complex research, analysis of the doctrinal positions of lawyers and current legislation of Ukraine. It is defined: peculiarities of legislative regulation of the status of a civil servant, criteria of division and categories of civil servants, general principles of activity and subjects of legal regulation of the status of a civil servant, general and special nature restrictions. The essence of the administrative and 
legal status of civil servants of the prosecutor's office, the court, internal affairs, and local self-government is disclosed. Their main components are determined, taking into account the differences between these categories of civil servants. The theoretically justified opinion on the ambiguity of the interpretation of certain provisions of the current Law of Ukraine "On Civil Service” and suggests ways to improve it.

\section{REFERENCES}

1. Бабенко В. I. Сутність адміністративно-правового статусу державних службовців органів прокуратури. Наше право. № 4.С. 56-59.

2. Битяк Ю. П. Державна служба в Україні: організаційноправові засади: монографія. Х.: Право, 2005. 304 с.

3. Битяк Ю.П. Державна служба в Україні: проблеми становлення, розвитку та функціонування: автореф. дис. ... докт. юрид. наук: 12.00.07. Х., 2016. 38c.

4. Васильківська В. В. Правове регулювання статусу державного службовця в Україні: автореф. дис. ... канд.. юрид. наук: 12.00.07. Одеса, 2018. 24 с.

5. Васильев А. С. Административное право Украины. Х.: Одиссей, 2002. 288 с.

6. Висновок на проект Закону України «Про державну службу» Верховного Суду України. [Електронний ресурс]. URL: http://www.scourt.gov.ua.

7. Державне управління: проблеми адміністративно-правової теорії та практики /за заг. ред. В. Б. Авер'янова. К.: Факт, 2003. 384 с.

8. Державне управління: теорія i практика / за заг. ред. В. Б. Авер'янова. К.: Юрінком Інтер, 1998. 432 с.

9. Дубенко С. Д. Державна служба і державні службовці в Україні. К.: Видавничий Дім «Ін-Юре», 1999. 242 с.

10. Загальна теорія держави та права: підручник / М. В. Цвік, О. В. Петров, Л. В. Авраменко та ін.; за ред. М. В. Цвіка, О. В. Петришина. Х.: Право, 2009. 584 с.

11. Золотарьова Я. С. Адміністративні процедури проходження державної служби в судових органах України: автореф. дис. ... канд. юрид. наук: 12.00.07. К., 2016. 24 с.

12. Іншин М. І. Особливості правового регулювання державної служби в Україні: сучасний стан, проблеми, перспективи розвитку. Форум права. 2013. № 2. С. 165-179.

13. Конституція України. Відомості Верховної Ради України. 1996. № 30. Ст. 141 (із змінами). 
14. Леліков Г. І. Організаційно-правові засади формування i функціонування державної служби в Україні: дис. ... канд. юрид. наук: 12.00.07. К., 1999. 173 с.

15. Мегедин I. В. Особливості правового статусу державного службовця. Науково-інформаційний вісник. Серія: «Право». 2013. № 7. C. 157-163.

16. Нижник Н. Р. Державна виконавча влада в Україні: формування та функціонування. К.: Вид-во УАДУ, 2000. Ч. 1. С. 166-167.

17. Падалко Г. В. Конституційно-правовий статус посадових осіб місцевого самоврядування в Україні. Держава $i$ право. Вип. 55. C. 184-190.

18. Петришин О. В. Статус службової особи: природа, структура, спеціалізація. К.: НМКВО, 1990.

19. Про державну службу: Закон України від 10 грудня 2015 р. № 899-VIII. Офіиійний вісник України. 2016. № 3. Ст. 149. [Електронний ресурс]. URK: http://zakon. rada.gov.ua.

20. Про судоустрій та статус суддів: Закон України від 7 липня 2010 р. № 2453-VI. Офіиійний вісник України. 2010. № 55/1. Ст. 1900.

21. Роз'яснення Національного агентства України з питань державної служби «Щодо віднесення посад керівників структурних підрозділів місцевих державних адміністрацій до відповідних категорій посад державної служби» від 10.05.2016 p. № 6-p/3 [Електронний ресурс]. URL: http://nads.gov.ua/page/shchodo-vidnesennyaposad-kerivnykiv.

22. Скакун О.Ф. Теория государства и права: учебник. Х.: Консум; Ун-т внутр. дел, 2000. 704 с.

23. Тихомиров Ю. А. Курс административного права и процесса. М., 1998. 799 с.

24. Юридична енциклопедія: в 6 т. /за заг. ред. Ю. С. Шемшученка та ін. К.: Українська енциклопедія, 2003. Т. 5: П-С. 736 с.

\section{Information about the author:} Lehka O. V.

Doctor of Law, Associate Professor, Head of Department of Criminal-Law Disciplines of the Dnipro Humanitarian University 35, Yermolovoi str., Dnipro, 49033, Ukraine 